\title{
Patent Legal Protection On Invention (Comparation Study Between Indonesia and Japan)
}

\author{
Salsabila Khairunnisa \\ Master of Law of Diponegoro University \\ JL. Imam Bardjo, SH No. 1 Semarang, 50241 \\ +628129905100/Salsabila22101995@gmail.com
}

\begin{abstract}
The development of technology is needed and cannot be separated from patent protection between WIPO's (World Intellectual Property Organization) member like Indonesia and Japan. This study discusses Indonesian patent protection law and its comparison toward invention between Indonesia and Japan. The study done through normative research methodology and analysed it comparatively. Indonesia has regulated the patent protection in Act Number 13 of 2016. The scopes are patent, simple patent, and also the period of patent protection for 20 years, while regular patent protected for only 10 years. Japan has arranged the patent protection in Japan Patent Act 21/1959 and it covers the patent and utility model. The time period for the patent protection is 20 years and for utility models is 6 years. The two countries have used common principle that is 'first to file'. Both nations have also required the same requirements which are the novelty of the invention, the beneficial of the product, and the invention steps. Litigation and non-litigation are the doors to resolve patent dispute.
\end{abstract}

Keywords: Legal Protection; Patent; Invention; First to File

\section{A. INTRODUCTION}

The current development of globalization has major influence on technological advance, especially in the face of today's global competition. The growth of technology is not only covers televisions and computers but also medicine, automotive, and pharmacy. The field of technology is one of the determining factors for the country's economic growth. The country's capability in grasping the world economy is an example that proves the existence of relationship between economic development and controlling technology. Therefore, a skillfull scientist and has numerous genuity products is usually rewarded by government to provide a conducive atmosphere to researchers (Utomo, 2010).

Technology is basically born from human intellectual initiative. It has material values or something of economic value, which can be an object of property. Legally, the right to intellectual power in the field of technology is recognized as an intangible property rights, that known as patents (Saidin, 2013). Accordingly, the products invented by experts are intellectual properties in which protected by law.

Regulations concerning intellectual property rights are inseparable from the Paris Convention for the Protection of Industrial Property (Paris Convention) on March 20, 1883 in Paris, France. The Paris Convention has undergone several 
changes. Most recently changes are in Stockholm in 1979 and in 2002. The Paris Convention principally regulates industrial property rights which include patents, utility models (industrial models and designs), trade design, trademarks, trade names and indication of source of appellation of origin (Saidin, 2013).

The term patent originally came from Latin patere which means opening up (for examination or being known by other parties). This term became popular since the first published of patent letter sourced from royal decrees signed by King Henry VI to a Flemish national inventor in 1449 (Munandar \& Sitanggang, 2011). In Indonesian law, the patent defined in Article 1 number 1 of Act Number 13 of 2016 as:

"an exclusive right granted by the state to the inventor for the results of his invention in the field of technology for a certain period of time implementing the invention itself or giving approval to other parties to implement it."

The right is exclusive, because the right is given only to the inventors who produces inventions. Through that given right, they can spread their invention by themselves or approve it to other parties to implement it, for example through a license (Saidin, 2013).

The World Intellectual Property Organization (WIPO) provides the following patent definitions:

"A patent legally enforceable right granted by virtue of a person to include, for a limited time, certain acts in relation to new invention; the privilege granted by a government authority as a matter of right to the person who is entitled to apply for it and who fulfills the prescribed condition" (Gumanti, 2015).

The invention in Article 1 number 2 of Act Number 13 of 2016 is an inventor's idea which is poured into a specific problem solving activity in the field of technology or product, or improvement and development of a product or its process. While inventor in Article 1 number 3 Law Number 13 of 2016 is a person or several people who jointly carry out the ideas and implemented it into activities that produce inventions.

Partial patents of industrial property rights play an important role in the process of country's industrialization. The patents are granted to support innovation and technological invention activities and it must be protected. If there is no adequate protection, it might be better for inventors to store the technology. In line with the protection right, the state usually asks inventors to reveal their inventions in patent specifications whose descriptions can be accessed widely, so that people can learn from it and it is hoped that the community will produce other inventions that are more advanced than the previous one (Parinduri 2013: 150).

In patent protection, if the provided scope of protection is too broad for patent holders, then the legal protection system has a very strong impact on the patents protection. Thus, the transfer technology will be difficult, because modifications are not easy, and even non-substantial modifications from other parties are still 
considered as violations of patent rights. Conversely, if the protection given to the holder of the patent is too narrow, then the holder of the patent is easily violated because the substantial modification is unconsidered as a violation of patent rights. Despite the possibility counterback, the narrow protection for patent right has a positive effect on the development of the country's technology (Yodo, 2016: 680).

On the other side, the 1988 patent reformation in Japan has expanded the scope of patent protection. Based on the 1988 patent law reform in Japan, empirical analysis of 307 Japanese companies during the period 1988 to 1994 found an enlargement of the scope of patent law including the R \& D project in Japanese companies (Sakakibara \& Branstetter, 2001).

It is possible that there are patents that has similarities one after another. Accordingly, Indonesia uses the principle of first to file and so does Japan. This principle used to acknowledge the patent for they who first to register it. On the contrary, there are countries which use principle of first to invent, in this case they who first to formulate will be patent-acknowledged. Nevertheless, both principles do not rule out the possibility that there are other parties who have similarities with patented inventions. On the basis of these two principles, the scope of patent protection from Japan and Indonesia is worth to know. Based on the background explained above, the problems that need to be studied are: (1) What is patent law protection in Indonesia, and (2) what is the comparison of patent legal protection against Indonesian and Japanese inventions.

\section{B. RESEARCH METHOD}

This research uses normative legal research method, the research focused on reviewing the application of the rules or norms of positive law (Ibrahim, 2006). The approach method in this study uses a comparative approach by comparing Indonesian patent law protection with Japan.

The data explained and described through descriptive analytical approach. It describes the conditions and facts in detail and systematic. The data sourced from secondary data sources, which are commonly used in normative research. The data sources used are: (1) Primary Legal Materials, namely: binding legal materials such as the most basic norms, the 1945 Constitution, Law Number 14 Year 2001 on Patent and have been amended by Law Number 13 Year 2016 on Patent and Japan ese Patent law 21/1959; (2) Sedondary Legal materials, which is the primary legal materials in the form of books, paper articles and scientific papers that are relevant to the issues examined relating to the legal protection of patents on inventions.

\section{DISCUSSION AND ANALYSIS}

\section{Patent Legal Protection in Indonesia}

Provisions concerning Patents are generally regulated in the Paris Convention on the Protection of Industrial Property Article 4, 4bis, 4ter, 4 quarter, 5, 5bis, 5ter, 
5quarter, which was set on March 20, 1883 (Darusman, 2016). In Indonesia Patents are one form of intellectual property protection and have been known since the days of the Dutch East Indies government with the introduction of Octrooiwet 1910S Number 33 and since 1989 this country has had a National Patent Law, that is Law Number 6 of 1989 (Sutedi, 2013). The Patent Law has been amended by Law No. 14 of 2001 concerning Patents. As time goes by, the Patent Law No. 14 of 2001 is not in accordance with the development of the law, so it was amended in 2016 with Law No. 13 of 2016.

Before the amendment of the Law No. 14 of 2001, there were several substances that were changed in previous version. The urgency of amending the Patent Law, among others: First, Adaptation to the Intellectual Property Administration Automation system because it is related to the Patent registration mechanism that can be submitted electronically as in Article 24 paragraph (4) of the New Patent Law states "Application as referred to in paragraph (2) may be submitted either electronically and non-electronically". Second, the clauses improvement of the provisions on patent using by Government. Three, exceptions to criminal and civil demands for parallel imports and bolar provisions. Four, inventions in the second use form (second use and second medical use) that have expired (public domain) are not allowed. Fifth, rewards for State Civil Apparatus researchers as inventors in which resulted from its commercialization. Sixth, improvement of provisions related to new inventions and inventive steps for publication in universities or scientific institutions nationwide. Seventh, patent may be used as fiduciary object. Eighth, the authorization of Appeals Commission to examine the request for correction of descriptions, claims or drawings after the application was granted as a patent and its cancellation. Ninth, patent can be transferred trhough waqf. Tenth, the clauses on the appointment and dismissal of examiner experts by the Minister. Twelfth, the arrangements related to force majeure in administrative and substantive examinations of the applications. Thirteenth, defense, export and import arrangements related to mandatory licenses. Fourteenth, there is a mediation mechanism before the criminal charges are committed. Fifteenth, open the widest opportunity to the national industry to utilize the patent which has ended its optimal period of protection and free from lawsuits and the obligation to pay royalties.

Patents, according to the General Dictionary of Indonesian Language, are derived from the word ocktrooi which in European language means a commercial letter or permit from the government stating that a person or company may make an item of his own income (other people may not make it). Oktroi (Indonesian term), patent (English), octrooi (Dutch), these words are defined as: a special right based on the law given to the opinion/the creator (uitvinder) or according to the law of the parties entitled to obtain it (de rechtverkrijgende), at his request submitted to the authorities, for new income, improvements to existing income, new ways of working, or creating a new improvement for a certain period of time (Sutedi, 2013). 
In law No. 13 of 2016, the protection period as shown in Article 22 is 20 years from the acceptance date and cannot be extended. Meanwhile, a simple patent in article 23 has a period of protection for 10 years and cannot be extended. It means, after the patent protection period has expired, it cannot be extended. As a result, when the status of the patent protection has expired, it automatically becomes public property (public domain) (Utomo, 2010).

There are two scopes of the patent protection under Article 2 of Law No. 13 Year 2016 which are patent and simple patent. The patents granted to new inventions that contain inventive steps and can be aplicated into industries. While simple patents given to new inventions, development of existing products or its processes, and can be aplicated in industries.

The new invention, according to Article 5 of Law Number 13 of 2016, is patented if the registered invention is not the same as previously revealed technology. The previously disclosed technologies are those that have been announced in Indonesia or outside Indonesia either in writing, oral descriptions or through demonstrations, its usages, or in other ways that allow an expert to carry out the invention before: (1) Receipt Date; (b) Priority Date (the application is submitted with Priority Rights).

Article 4 of Law No. 13 of 2016 states that not all inventions in the field of technology can be proposed, which are: (1) aesthetic creations, (2) schemes, (3) rules and methods for carrying out activities including (involving mental activities, games, and business), (4) rules and methods that only contain computer programs, (5) presentations on information; and (6) findings (discovery) in the form of new usages for existing and/or known products; and/or new forms of existing compounds that do not produce significant efficacy enhancements and have chemical structure differences.

The term of containing inventive steps, compared to other conditions is the most subjective conditions. The benchmark or measure used in the Indonesian Patent Law to test this requirement is based on the quality of non-obvious inventions for someone who has certain expertise in the technical field. What is meant by someone with certain expertise in this Law is the patent examiner expertise (Utomo, 2010). The requirement for an inventive step that is associated with a non-obviousness requirement is to ensure that protected inventions are truly creative and inventive innovations where a person cannot easily create or create something that has been existed before (WIPO, 2006: 12). Unfortunately, the Law No. 14 of 2001 and Law No. 13 of 2016 on Patent regulate no details regarding inventive steps, consequently, this requirement is not easily understood by ordinary people.

In the explanation of Article 8 of Patent Law No. 13 of 2016, inventions in the form of products that can be applied in industry must be able to be made repeatedly 
(in a bulk) with the same quality. Whereas, if the invention is a process then the process must be practicable. Article 9 of Law No. 13 of 2016 states that the invention cannot be granted to the several matters: (1) process or product that its publications and its implementation is contradicted with legislation, religious morality, public order, or ethics; (2) the examination method, treatment and/or surgery which applied to humans or animals; (3) theories and methods in the field of science and mathematics, or all living things, except microorganisms, biological processes that are essential for developing plants or animals.

As regulated in Article 10 of the Patent Law No. 13 of 2016, the one who obtain a patent is the inventor. In another side, the patent right can be transferred from the inventor to the second party through the licensing agreement between both parties. If the invention is jointly produced by several people, the right of invention is equally owned by all Inventors. In the case that inventors incapable to produce their discoveries as mandated by the Indonesian Patent Law, the inventors usually sell their invention to the investor to be the next patent holder. However, the name of the inventors who produce the invention are still mentioned in the patent certificate (Utomo, 2010). The inclusion of those names, according to the Article 12 paragraph (6), is based on moral rights which attached always to the inventors even though the ownership has been transferred to another party.

\section{Comparison of Patent Legal Protection Against Indonesian and Japanese Inventions}

Regulating patent rights in Japan applied based on the Japan Patent Act 21/1959. The law's arrangements in Japan are heavily influenced by American patent law. Japan esteems that American Patent system considered a balanced system in determining the extent of patent protection (Purwaningsih, 2015). This act then revised and amended to the latest act in 2006.

The definition of invention in Japan Patent Act is explained in Article 2 paragraph (1), it is the highly advanced creation of technical ideas utilizing the laws of nature. A good invention is potentially patented if it meets the novelty criteria, utility, and follow the inventive step requirements. The novelty criteria in Japan, according to Article 29 Japan Patent Act is a new invention which generally known and has been operated by Japanese and other countries during the submission of inventions in Japan Patent Office (Cohen, 1994).

Regarding inventive step requirements in Article 29 of Japan Patent Act, it is stated that if an invention is easily made (it can be made by someone who has ordinary expertise in special skills), before filing a patent application, then patent rights cannot be granted to him. New inventions can be patented to obtain exclusive rights if the applicable conditions are met. One important feature of the Japanese patent system is industrial usefulness and design. The levels needed in a utility model invention are measured from the scope and patent time period. 
Registration of patents on Japanese patent systems follows first to file rules. With a first to file system, many Japan companies are competing to register their investment as quickly as possible. During the 15 months the proposers can change the application after submitting to the Japan Office Patent (JPO). If two or more applications are bringing the same invention and submitted on the same date, inventors are required to reach an agreement to determine who will get the patent amongst them (Maskus \& McDaniel, 1999).

In early independence, Indonesia used 'first to use' under the regulation of brand No. 21 of 1961. The brand registered through this concept according to its 2 nd article paragraph (1) and (2). The first to use is that the brand (registered brand) holder owned the exclusive right of the brand. The registered brand considers the holder to be its first user and does not to justify the right owner of the brand. This concept then amended for its current unsuitable condition. Thus, Indonesia has changed the concept from 'first to use' to 'first to file' (Maulana, 1999; Murjiyanto, 2017).

The Japanese patent system has two models, namely utility model law and patent law. The patent system protects high-level inventions, and utility models protect the daily fields tools or toys, where a very popular product is created with little change from the latest product. Utility model systems are created to protect such items or simple inventions that do not require technical sophistication. The utility model law limits its protection for tools or construction designs. Therefore, the processes or materials which protected through patent law are not protected by the utility model law (Purwaningsih, 2005).

Patent system has a substantive inspection system. It is granted after prior article tracking and strict inspection of the invention conditions, such as novelty, and inventive step. In contrast, the utility model system adopts a non-substansive inspection system (Purwaningsih, 2005). The patent period in Japan is given for 20 years from the patent registration date. Especially for pesticides and medicines, both can be extended according to Article 67 Japan Patent Act. As for the model utility, the registration applicant must pay an application and registration fee and get a term of protection for 6 years.

Japan has two professional forms in the field of patent law and intellectual property law called Bengoshi and Benrishi. Bengoshi and Bemrishi usually consist of lawyers and public prosecutors. Bengoshi specified for patents, while Benrishi can prosecute patents and trademarks. Laws in Japan prohibit partnerships between Japanese and American lawyers. Lawyers from outside Japan may only give advice to their company outside the court. A lawyer from outside Japan who can represent his client in court is only a lawyer born in 1955. In addition, an inventor who is not a permanent resident or domiciled in Japan cannot submit his own patent application. 
An inventor with the above conditions must be represented by Benrishi or Bengoshi (Hill \& Murata, 2007).

Arising problems in patent are usually about who first discovered an invention and conflict between parties on patent transfer agreement. It can be said that dispute resolution can be divided into three types (Djumhana \& Djubaedillah, 2008):

a. Dispute resolution using negotiations, both in the form of direct negotiations (simple negotiation) and third party participation (mediation and reconciliation).

b. Dispute resolution by means of litigation, both national and international.

c. Dispute resolution by using arbitration.

The three dispute resolution models above are through litigation and nonlitigation mechanism. The litigation path (ordinary court) is a mechanism for resolving cases through legal approach in the court in accordance with the laws and regulations. Basically, litigation is the last resort or ultimum remedium (Sutiyoso, 2008: 5). It is the last attempt if the problems are unresolved. While the non-litigation path (extraordinary court) is a settlement mechanism outside the court using living mechanisms in the community such as deliberation, peacefully agreement, kinship principle, customary settlement, and others.

Basically, everyone hopes that the problems occurred in patent context can be resolved through a judicial institution. However, the reality is different because the settlemen process through the courts takes a long time and costs a lot of money. Seeing such reality then arise the anti litigatition movement (Djumhana \& Djubaedillah, 2008). The thought of anti litigation was applied in Law No. 14 of 2001 and Law No. 13 of 2016 on Patents. Both Indonesia and Japan are practicing the two mechanisms in order to resolving the problems in patent context.

\section{CONCLUSION}

Patent protection in Indonesia covers two types, both are patents and simple patents. Patents are intended for new inventions that contain inventive steps and industrially operable. While simple patents are given for new inventions, development of production methods that already exist and it industrially workable. The term of patents protection is 20 years and cannot be extended. On the other side, simple patents protect its owner for 10 years and cannot be extended. Patents are an exclusive right that is not directly owned by the inventor. The right of patents granted for he/she who first to file the invention. Thus, Indonesia is holding a 'first to file' principle to grant patent for the inventions.

Different from Indonesia, Japan has two system of patent protection which are patents and utility model system. Patents are given after a substantive examination and must meet the novelty requirements, inventive steps of an invention and whether there is inconsistency in the invention specifications. On contrary, the utility model 
system does not require substantive examination to provide protection to the inventor. In case there are problems related to acclaimed patent illegally, Indonesia and Japan both have same mechanisms for dispute resolution; through litigation and non-litigation process.

\section{REFERENCES}

Cohen, M. S. (1994). Japanese Patent Law and the WIPO Patent Law Harmonization Treaty: A Comparative Analysis. Fordham Intellectual Property, Media and Entertainment Law Journal, 4(3), 847-890.

Darusman, Y. M. (2016). Kedudukan Serta Perlindungan Hukum Bagi Pemegang Hak Paten dalam Kerangka Hukum Nasional Indonesia dan Hukum Internasional. Yustisia Jurnal Hukum, 5(1), 203-215.

Djumhana, M., \& Djubaedillah, R. (2008). Hak Milik Intelektual Sejarah: Teori dan Praktiknya di Indonesia. Bandung: PT. Citra Aditya Bakti.

Gumanti, R. (2015). Perlindungan Hukum Terhadap Hak Paten di Indonesia. Al-Mizan, 11(1), 196-210.

Hill, D. W., \& Murata, S. (2007). Patent Litigation in Japan. Akron Intellectual Property Journal, (109), 141-184.

Ibrahim, J. (2006). Teori dan Metodologi Penelitian Hukum Normatif. Malang: Banyumedia Publishing.

Maskus, K. E., \& McDaniel, C. (1999). Impacts of the Japanese patent system on productivity growth. Japan and the World Economy, 11(4), 557-574.

Maulana, I. B. (1999). Perlindungan Merek Terkenal Di Indonesia Dari Masa Ke Masa. Bandung: PT. Citra Aditya Bakti.

Munandar, H., \& Sitanggang, S. (2011). Mengenal HAKI Hak Kekayaan Intelektual Hak Cipta, Paten, Merek dan Seluk Beluknya. Jakarta: Erlangga.

Murjiyanto, R. (2017). Konsep Kepemilikan Hak Atas Merek di Indonesia (Studi Pergeseran Sistem "Deklaratif" ke dalam Sistem "Konstitutif"). Jurnal Hukum IUS QUIA IUSTUM NO, 24(1), 52-72.

Purwaningsih, E. (2005). Seri Perkembangan Hukum Intelectual Property Rights. Bogor: Ghalia Indonesia.

Purwaningsih, E. (2015). Seri Hukum Hak Kekayaan Intelektual Hukum Paten. Bandung: CV.Mandar Maju.

Saidin, H. O. (2013). Aspek Hukum Hak Kekayaan Intelektual (Intelectual Property Rights). Jakarta: Rajawali Press.

Sakakibara, M., \& Branstetter, L. (2001). Do Stronger Patents Induce More Innovation? Evidence from the 1988 Japanese Patent Law Reforms. The RAND Journal of Economics, 32(1), 77-100.

Sutedi, A. (2013). Hak Atas Kekayaan Intelektual. Jakarta: Sinar Grafika.

Utomo, T. S. (2010). Hak Kekayaan Intelektual (HKI) di Era Global. Yogyakarta: Graha Ilmu. 